\title{
Postnephrectomy arteriovenous fistula
}

\author{
Hospital: Beneficência Portuguesa, Universidade Federal de São Paulo - São Paulo, Brazil
}

\begin{abstract}
The development of the postnephrectomy arteriovenous fistula (PNAVF) between the renal vessels stumps is rare. Here we present a case report of PNAVF, and review the diagnosis, treatment and prevention. The most common clinical features include a loud murmur over the previous nephrectomy scar, and heart failure resistant to common medical treatment. A 58-year-old white woman was admitted to the hospital for a complete evaluation of an unexplained congestive heart failure with no response to common medical treatment. She had had a right nephrectomy for pyonephrosis 13 years before. The diagnosis of PNAVF was suspected because over the right lumbar region a definite trill was palpated, and on auscultation a harsh, machinery-like murmur was heard. The diagnosis was confirmed by aortogram and selective renal arteriography. In May 1989, the right arteriovenous was excised through a right subcostal transperitoneal approach. The renal vessel stumps were individually ligated and sutured separately close to aorta and vena cava. The patient's postoperative course was entirely uneventful in the following seven years. We conclude that during nephrectomy, the renal vessels should be ligated separately, and the transfixation in mass of the stumps avoided to prevent arteriovenous fistula.
\end{abstract}

UNITERMS: Arteriovenous fistula. Renal vessels. Nephrectomy. Heart failure.

\section{INTRODUCTION}

$\mathrm{T}$ he development of the postnephrectomy arteriovenous fistula (PNAVF) is a rare complication of a common surgical procedure. ${ }^{1-3}$

Mass ligation and transfixation of the renal vessels in nephrectomy, although commonly practiced, is condemned by many surgeons as favoring the development of arteriovenous fistula. ${ }^{1.45}$ We present a case of the postnephrectomy arteriovenous fistula, review the literature and discuss the diagnosis, treatment and prevention.

\section{Address for correspondence:}

José Carlos Costa Baptista-Silva

Rua Prof. Artur Ramos, 178, 123-Vega

São Paulo /SP - Brasil - CEP 01454-904

\section{CASE REPORT}

R.S., a 58-year-old white woman, was admitted to the Beneficência Portuguesa Hospital with an unexplained congestive heart failure nonresponsive to common medical treatment. The patient had undergone a right nephrectomy 13 years earlier for pyelonephrosis, and had been presenting symptoms of gallbladder lithiasis with surgical indication.

Upon physical examination, blood pressure was $150 /$ $80 \mathrm{mmHg}$ and the cardiac rate was $96 \mathrm{bpm}$. A trill was palpated over the right lumbar region and a loud, continuous machinery-like murmur was heard upon auscultation over the right flank. Eletrocardiography revealed left ventricular hypertrophy and arrhythmia, and chest roentgenograms showed a minimal cardiomegaly and slight vascular congestion. All laboratory tests were within normal limits.

With a suspicion of a systemic arteriovenous fistula, a percutaneous transfemoral abdominal aortogram and a 
selective renal arteriography were performed. Arteriographic studies revealed a dilated right renal artery with a diameter of $10 \mathrm{~mm}$. At a point $3 \mathrm{~cm}$ from its aortic origin, the contrast medium coursed through a winding channel and entered the inferior vena cava, and a large arteriovenous fistula between the renal artery and vena cava at the site of previous right nephrectomy was revealed. The i ferior vena cava proximal to the renal vessels stumps was dilated and had a maximum diameter about $40 \mathrm{~mm}$ (Fig. 1).

On May 3, 1989, correction of the fistula was carried out through a right subcostal transperitoneal incision. A pulsating mass about $2 \mathrm{~cm}$ in diameter was found near the right renal vessel stumps. The renal vessel stumps were isolated, ligated and divided. The sac (fistula) was individualized and removed. The renal artery and vein stumps were individually ligated with 2-0 silk, and sutured separately with monofilamentar polypropylene close to aorta and vena cava respectively. The retroperitoneum was closed, and the cholecystectomy was carried out.

The patient's postoperative course was entirely uneventful. The murmur and trill disappeared after the procedure. The patient was discharged from the hospital five days later on May 8 without any complications. In March 1996, the patient was asymptomatic and clinical examinations revealed no sign of heart failure. Blood pressures, analytic tests and pulse were within normal limits, and the cardiomegaly was reduced. An abdominal ultrasonography was within normal limits, except for the absence of the gallbladder, right kidney and arteriovenous fistula (postoperative status).

\section{DISCUSSION}

Renal arteriovenous fistula can be idiopathic, congenital or acquired ${ }^{4.6}$ Postnephrectomy renal arteriovenous fistulas are rare complications that may develop over a period of time ranging from days to 35 years. $^{2,7.8}$ In 800 renal transplants performed at the University of Minnesota, this complication has occurred only twice, and may well have been caused by simultaneous ligation of renal artery and renal vein. ${ }^{7}$

Factors considered to be of etiologic significance in the development of postnephrectomy arteriovenous fistula include: mass ligation of the renal pedicle, especially when transfixation sutures are used; nephrectomy for tuberculosis of the kidney; postoperative infection in the nephrectomy bed, and; renal carcinoma. ${ }^{2-5,8-10}$ The mechanism of fistula formation was clear in some of the cases. Those which developed following nephrectomy were likely due to ligation in mass of vessels, with subsequent necrosis of the wall and perforation. Similar changes occurred after direct trauma. In congenital lesions, the large vessels made up the fistula.

Among the cases of hypernephroma, there frequently existed both a connection of large artery to the vein due to tumor invasion, and large communicating vascular spaces within the partially necrotic tumor. ${ }^{4}$ In the remaining cases, the initial lesion probably was an arterial aneurysm which eventually eroded the wall of the vein to form the connection, but this condition is rare. ${ }^{4.11}$

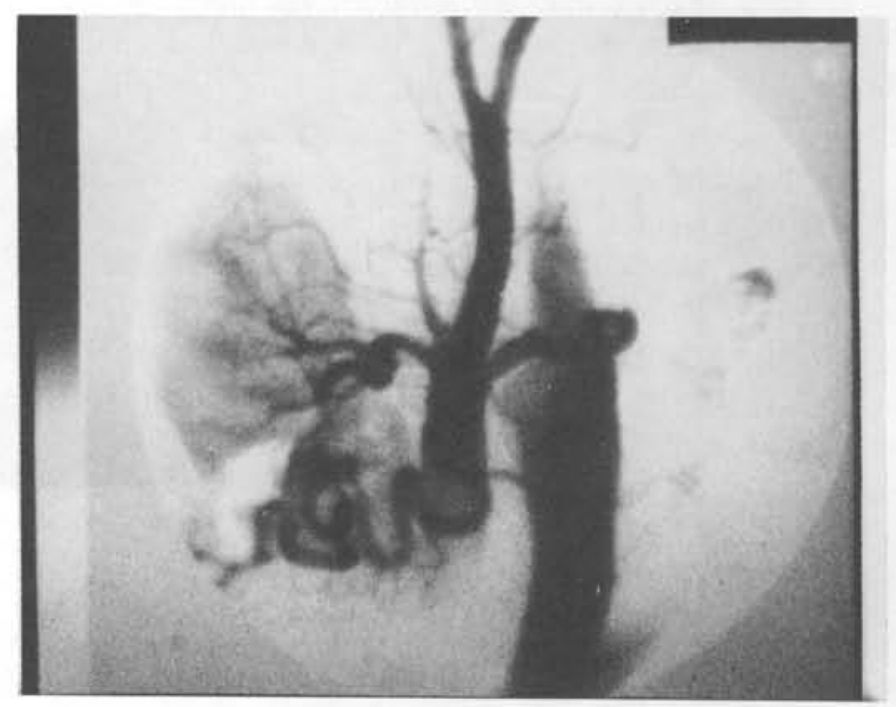

Figure 1 - Percutaneous retrograde abdominal aortogram demonstrates dilated right renal artery, winding stump of the renal vein, and opacification of inferior vena cava.

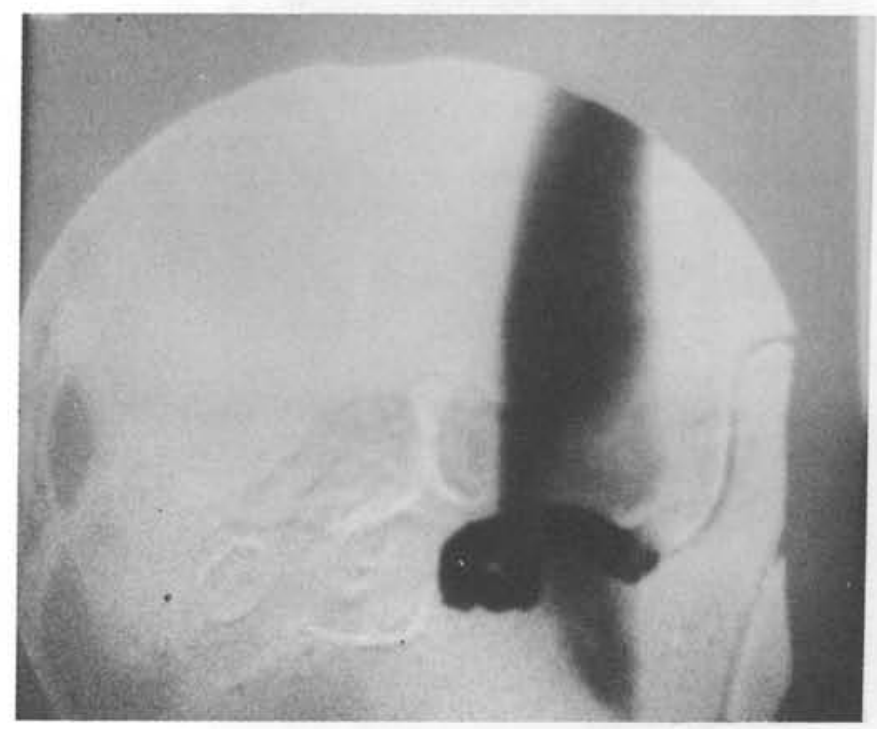

Figure 2 - Percutaneous retrograde renal arteriogram demonstrates dilated right renal artery, tortuous stump of the renal vein, and opacification of inferior vena cava. 
The literature has recorded more frequent involvement of the right postnephrectomy renal arteriovenous fistula because of the anatomic disposition of the right kidney and a short renal vein pedicle. Twothirds of the cases are found on the right side; removal of the kidney is technically more difficult on this side. ${ }^{2,712,13}$

Like all peripheral arteriovenous fistula, they create a high venous return, an increase in cardiac output, and sometimes, a rise in systolic blood pressure. This leads to a reduction in peripheral resistance and a decrease in diastolic blood pressure. If the heart cannot compensate for this shunt while trying to meet increased tissue demands, high output cardiac failure will naturally result. ${ }^{4}$

Postnephrectomy renal arteriovenous fistula must be suspected in all patients with a history of previous nephrectomy when congestive heart failure and a high cardiac output state are present, especially if resistant to common medical treatment. ${ }^{2.14}$ The clinical presentation of this syndrome is very impressive because many patients have symptomatic congestive heart failure, high cardiac output, hypertension and continuous abdominal murmur. ${ }^{4}$

With the clinical manifestations of an increased cardiac output, hyperthyroidism, anemia, beriberi heart disease, Paget's disease and an intracardiac shunt as mentioned should be considered in the differential diagnosis. The pertinent clinical features of these various conditions will not be discussed at this time but a complete physical examinations, fluoroscopy of the chest, and a few laboratory studies will usually suffice to distinguish the various disorders.

The duplex scan ultrasound, helical. 3-D (spiral) computer tomography and magnetic resonance angiographic images are alternative imaging modalities for the aorta and its branches, but definitive diagnosis is made by abdominal aortogram and selective renal arteriogram in case of the PNAVF. . $^{1.2,4.14-16}$

Treatment can be accomplished through embolization or occlusion of the fistula through angiographic techniques, but the possibility of pulmonary emboli exists. Most surgeons prefer surgical excision and ligation of the fistula. ${ }^{17-19}$ In our patient, we preferred surgical procedure to treat the arteriovenous fistula and the gallbladder lithiasis at the same time. We concluded that during nephrectomy, the renal vessels should be ligated separately, and the transfixation in mass avoided in order to prevent the arteriovenous fistula.

\section{Resumo}

O desenvolvimento de fístula arteriovenosa entre os cotos dos vasos renais pós-nefrectomia (FAVPN) é raro. O objetivo é relatar um caso de FAVPN, suas causas, diagnóstico e tratamento. Era uma mulher de 58 anos submetida a nefrectomia direita há 13 anos, que se apresentou com insuficiência cardiaca congestiva de difícil controle. O diagnóstico clínico da FAVPN foi feito devido o sopro contínuo com reforço sistólico no flanco direito e confirmado pela arteriografia. O tratamento foi a ressecção dessa fístula e sutura dos cotos vasculares separadamente junto às suas origens. Houve boa evolução e cura da FAVPN no acompanhamento nestes últimos sete anos. Concluímos que durante a nefrectomia: os vasos renais deve ser ligados ou suturados separadamente, evitando a transfixação em monobloco dos cotos dos vasculares para prevenir fístula arteriovenosa

\section{REFERENCES}

1. Giordanengo F, Giorgetti PL, Morbidelli A, Miani S, Berreta L, Vandone PL. Fistola artero-venosa del peduncolo renale sinistro dopo nefrectomia - caso clínico. Minerva Chir 1991;46:1267-70.

2. Mateo AM, Larrañaga JR, Vaquero $C$, Rodriguez $S$, Samos RF. Postnephrectomy arterionevous fistula. J Cardiovasc Surg 1988;29:491-3.
3. Muller WH, Goodwin WE. Renal arteriovenous fistula following nephrectomy. Ann Surg 1956;144:240-2.

4. Messing E, Kessler R, Kavaney PB. Renal arteriovenous fistulas. Urology 1976;8:101-7.

5. Schwartz JW, Borski AA, Jannke EJ. Renal arteriovenous fistula. Surgery 1955;37:951-4.

6. Maldonado JE, Sheps SG, Bernatz E, Deweerd JH, Harrison EG. Renal arteriovenous fistula. Am J Med 1964;37:499-513. 
7. Castañeda-Zúñiga WR, Murthy T, Murphy W, Beraneck J, Amplatz K. Nonsurgical close of large arteriovenous fistulas. JAMA 1976;236:2649-52.

8. Grace JT, Staubitz W, Lessman F, Egan R. Intrarenal arteriovenous fistulas. Arch Surg 1960;81:58-62.

9. Dubost $\mathrm{CH}$, Piwnica A, Mathis PH, Fontanelle J. Les fistules arterioveineuses du pédicle rénal après nephrectomie. J Chir 1965;89:1-22.

10. Esquivel EL, Grabstald $H$ Renal arteriovenous fistula following nephrectomy for renal cell cancer. J Urol 1964;92:367-73.

11. Hollingsworth EW. Arteriovenous fistula of the renal vessels. AM J Med Sci 1934;188:399-403.

12. Lacombe $M$, Nussaume $O$, Jungers $P$. Les fistules artérioveineuses du pédicle rénal après nephrectomie. Ann Chir Thorac Cardiovasc 1973;12:91-7.

13. Pavanello PM, Colombati M, Pagliari M. Fistola arterovenosa del peduncolo renale postnefrectomia. Ann Ital Chir 1980;52:485-95.
14. Shirey EK. Cardiac disease secondary to postnephrectomy arterionevous fistula. Cleveland Cl Quart 1959;26:188-200.

15. Gomes MN, Davros WJ, Zernan RK. Preoperative assessment of abdominal aortic aneurism: The value of helical and three-dimensional computer tomography. J Vasc Surg 1994;20:367-76.

16. Rubin GD, Walker P, Dake MD. Three-dimensional spiral computed tomographic angiography: An alternative imaging modality for the abdominal aorta and its branches. J Vasc Surg 1993;18:656-64.

17. Ballanger P, Coqueran JE, Fontan F, Ballanger R. Fistules artério-veineuses du pédicle rénal après néphrectomie. J Urol Néphol 1978;6:387-90.

18. Marcaggi X, Boyer L, Lusson JR, Ribal JP, Viallet JF, Cassagnes J. Fistule artérioveineuse du pédicle rénal postnéphrectomie responsable de défaillance cardiaque. Arch Mal Coeur 1990;83:1721-4.

19. Young AT, Tadavarthy SM, Yedlicka Jr JW, et al. Vasculary embolotherapy. In: Castañeda-Zúñiga WR, Tadavarthy SM, eds. Interventional radiology. 2nd ed. Baltimore: Williams \& Wilkins, 1992:9-200. 